\title{
DISCRETE-PULSED ENERGY INPUT (DPIE) IS A PERSPECTIVE WAY TO DEVELOP RESOURCE AND ENERGY SAVING TECHNOLOGIES IN THE FOOD INDUSTRY
}

\section{Obodovych O. M., Sydorenko V. V.}

\section{INTRODUCTION}

According to the International Standard Industrial Classification of All Economic Activities (ISIC), food production is classified in the manufacturing industry, with its own divisions, which include food production, beverage and tobacco production; in the food production subdivision, 13 sectors are identified, including dairy, butter and fat, starch, bakery, sugar, macaroni, ready-to-eat food, livestock feed production.

The production of beverages covers the production of soft drinks and mineral water, the production of alcoholic beverages obtained mainly through fermentation, beer, and wine, the production of distilled alcoholic beverages.

All the diversity of food processing technologies is related to the implementation of processes, which can be divided into four main groups: mechanical, hydromechanical, thermal, mass transfer. A large and promising section of technology - biotechnology - is currently under development ${ }^{1}$.

The basic processes in food technology include mixing, homogenization, dispersion, emulsification, heating. One of the priority areas for technology advancement in the food industry is the effective combination of multiple processes and the intensification of these processes over time and by degree of impact.

One of the methods that allow to successfully solve the problem of intensification of these processes is the method of discrete - pulsed

\footnotetext{
${ }^{1}$ Иванец В.Н., Бакин И.А., Ратников С.А. Процессы и аппараты пищевых производств: Учебное пособие. Кемерово: Кемеровский технологический институт пищевой промышленности, 2004. 180 с.
} 
energy input (DPIE), developed at the Institute of Engineering Thermophysics of NAS of Ukraine ${ }^{2}$.

The method is implemented in several types of equipment, the most common of which is the rotor-pulsating apparatus (RPA), or high shear mixer (HSM), high shear reactor (HSR), rotor-stator mixer, or high shear homogenizer in English literature. The RPA usually consists of coaxial stator (-s) located in the housing, and a rotor (-s) in the form of shells with rectangular holes cut through them ${ }^{3}$.

In the food industry, a common application of high-shear mixers is to create emulsions of both high and low viscosity (salad dressings, sauces, curd fruits and dairy desserts, mashed potatoes, sauces, creams). In these products, high-shear mixing also helps disperse thickeners. High shear mixing is also employed to disperse artificial sweeteners and clouding agents in fizzy drinks. High-shear mixers are utilized both for processing of single and multiphase systems. In single phase systems they are very efficient in blending miscible liquids of very different viscosities (e.g., corn syrup and water); in multiphase systems they are used to emulsify immiscible liquids (e.g., mayonnaise, sauces), to deagglomerate and uniformly disperse (nano) particles in liquids (e.g., salt and sugar in water, corn flour in water), and also to suspend fine air bubbles (e.g., ice (cream) ${ }^{4}$.

In past years, the DPIE method was used in the technology of production of condensed milk ${ }^{5}$, for the intensification of the production of glucose-fructose syrups ${ }^{6}$, homogenized soybean paste preparation for

${ }^{2}$ Микро- и наноуровневые процессы в технологиях ДИВЭ: Тематический сборник статей /под общей ред. А.А. Долинского; Институт технической теплофизики НАН Украины. К.: Академпериодика, 2015. 464 с.

${ }^{3}$ Накорчевский А.И., Басок Б.И., Рыжкова Т.С. Гидродинамика роторнопульсационных аппаратов. Инженерно-физический журнал. 2002. Т. 75, № 2. C. 58-68.

4 Rodgers T. High-Shear Mixing: Applications in the Food Industry [Електронний ресурс] / T. Rodgers, L. Trinh // Elsevier BV. - 2016. - Режим доступу до ресурсу: https://doi.org/10.1016/B978-0-08-100596-5.03095-X.

5 Басок Б.И., Ободович А.Н., Мартыненко М.П., Коба А.Р., Горячев О.А. Интенсификация технологии производства сгущенного молока с сахаром посредством роторно-пульсационных аппаратов. Промышленная теплотехника. 2005. Т. 27, № 1. С. 38-41.

${ }^{6}$ Ободович А.Н., Хибина М.А., Боряк Л.А., Ободович А.А., Тесля А.И. Интенсификация производства глюкозо-фруктозных сиропов за счет механохимической деструкции. Промышленная теплотехника. 2006.Т. 28, № 3. C. 44-49. 
baby food developed and implemented on the basis of the method ${ }^{7,8,9}$, etc.

\section{Application of the DPIE method in technologies for processing starch-containing raw materials}

One of the most important types of food raw materials is cereal grains. Cereal grain is the raw material for a number of food industries, and its pre-treatment to release starch and other nutrients is necessary.

Studies of the influence the DPIE method on processing starchy raw materials were carried out to determine the dependence of its quality of processing on the following factors:

- physical factors (angular speed of rotation of the rotor, velocity of the flow of medium, the gap between the rotor and the stator, the frequency of flow pulsations, the number of processing cycles) on the average surface size of the particles:

- influence of thermal effects on its dispersion.

The studies were carried out on an experimental setup, the appearance of which is presented in Fig. 1.

In the first stage of the experiments, the angular rotational speed of the rotor and the number of processing cycles were changed. The angular speed of rotation of the rotor was changed by means of a frequency converter. Table 1 shows the dependence of the change of the average surface particle size on the angular speed of rotation of the rotor and the number of processing cycles of the water/grain mixture. The gap between the stator and the rotor was 500 microns.

These data suggest that with increasing number of processing cycles and angular speed, the surface average particle size of the processed grain raw materials decreases.

7 Басок Б.И. Пироженко И.А., Булавка Д.В. Дисперсный анализ соевой пасты, полученной при роторно-пульсационной гомогенизации. Промышленная теплотехника. 2003. Т.2 5, № 4. С. 88-92.

8 Грищенко А.В., Терлецкая Я.Т., Шаркова Н.А., Жукотский Э.К. Разработка высокобелковых композиций на соевой основе для лечебнопрофилактического питания. Промышленная теплотехника. 2003. Т. 25, № 4. C. $115-116$.

${ }^{9}$ Шаркова Н.О., Жукотський Е.К., Грищенко Г. В. Особливості технології виробництва соєвих продуктів. Промышленная теплотехника. 2004. Т. 26, № 6. C. 93-96. 


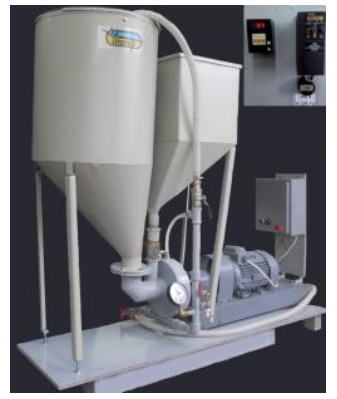

a)

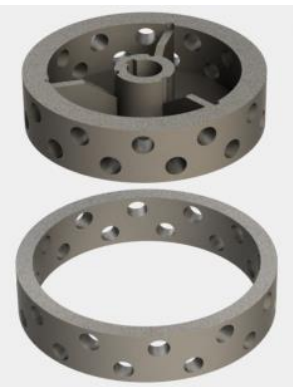

b)

Fig. 1. Experimental setup to determine the effect of the processing of starchy raw materials by the DPIE method on its quality properties.

a) view of the setup; b) the rotor-stator assembly

Table 1

The dependence of the surface average particle size of grain raw materials on the angular speed and the number of processing cycles

\begin{tabular}{|c|c|c|c|}
\hline Sample & $\begin{array}{c}\text { Number of } \\
\text { cycles }\end{array}$ & Angular speed, $\mathbf{s}^{-1}$. & $\begin{array}{l}\text { Surface average } \\
\text { particle size, } \mu \mathrm{m} \text {. }\end{array}$ \\
\hline 1 & 3 & \multirow{5}{*}{180} & 700 \\
\hline 2 & 5 & & 570 \\
\hline 3 & 10 & & 500 \\
\hline 4 & 20 & & 420 \\
\hline 5 & 30 & & 350 \\
\hline 1 & 3 & \multirow{5}{*}{300} & 660 \\
\hline 2 & 5 & & 510 \\
\hline 3 & 10 & & 400 \\
\hline 4 & 20 & & 310 \\
\hline 5 & 30 & & 260 \\
\hline 1 & 3 & \multirow{5}{*}{420} & 640 \\
\hline 2 & 5 & & 480 \\
\hline 3 & 10 & & 390 \\
\hline 4 & 20 & & 280 \\
\hline 5 & 30 & & 220 \\
\hline
\end{tabular}

In subsequent studies, the effect of the gap thickness between the stator and the rotor on the dispersion process was studied. The angular speed was unchanged at $300 \mathrm{~s}^{-1}$. 


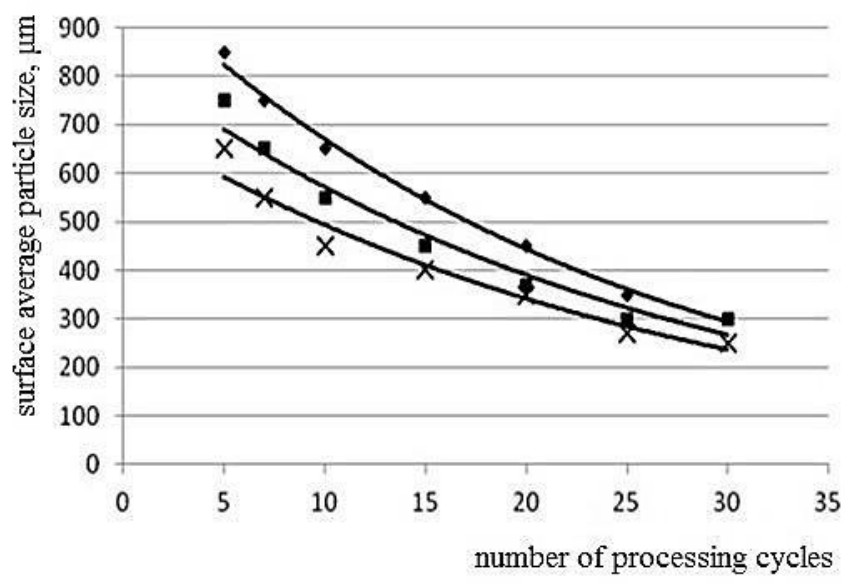

Fig. 2. Dependence of the surface average particle size of the grain raw material on the thickness of the gap and the number of processing cycles. : $-300 \mu \mathrm{m} ;-500 \mu \mathrm{m} ; \mathrm{x}-700 \mu \mathrm{m}$

The curves shown in Fig. 2, indicate that as the gap between the stator and rotor decreases and the number of processing cycles increases, the surface average particle size decreases.

The dispersion is influenced by the amount of solid phase in the processed medium ${ }^{10}$. Experiments were conducted to determine the effect of the solid phase content on the average surface particle size. The solids content of the mixture was $10,30,50 \%$ by weight of the water/grain mixture. The studies were carried out at an angular speed of rotation of the rotor $300 \mathrm{~s}^{-1}$, the gap between the rotor and the stator $500 \mu \mathrm{m}$, a frequency of flow pulsation of $3 \mathrm{kHz}$. The data of the experiments are presented in Fig. 3.

${ }^{10}$ Долинский А.А., Басок Б.И. Роторно-импульсный аппарат. 2. Локальный импульсный нагрев жидкости. Промышленная теплотехника. 1999. Т. 21, № 1. C. 3-5. 


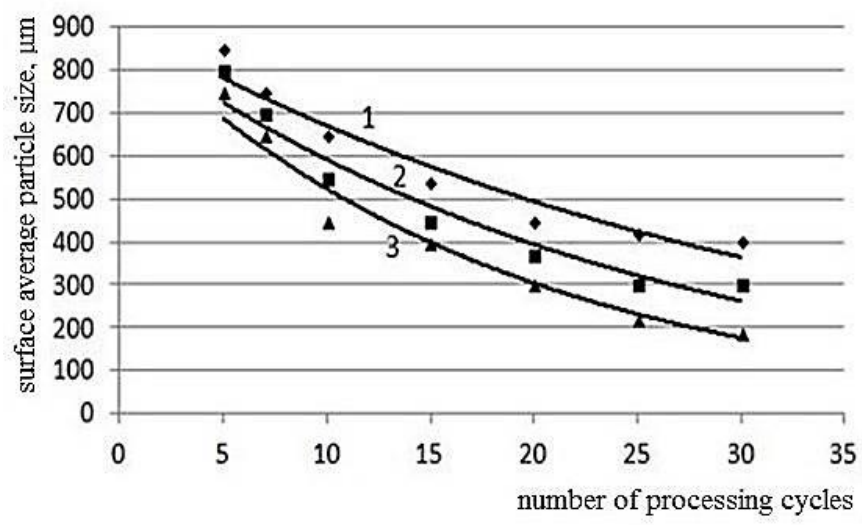

Fig. 3. The dependence of the surface average particle size of the grain raw material on the amount of solid phase and processing cycles

The graph shows that with the increase in the amount of solid phase and processing cycles, the surface average particle size decreases. It is most effective to process grain raw materials with a solids content of $50 \%$. However, after 20 processing cycles, all particles have a surface average size of less than 300 microns. This is because in the processing of the mixture shock loads occur not only due to the contact of solids with the working surfaces of the RPA, but also with each other. The more solid phase in the mixture, the greater the shock load of the particles among themselves.

It is known that in a number of technologies related to grain processing, it is pre-soaked ${ }^{11}$.

In the process of grain soaking, the aim of changing the structure of the protein, which binds starch grains, weakens the bonds of starch grains, converts the grain shell from semi-permeable to fully penetrated, is achieved ${ }^{12}$. Soaking grains is one way of softening them. The grain in the water absorbs moisture and increases in volume; the hydration of cellulose membranes increases their elasticity. Water creates layers

${ }^{11}$ Мальцев П.М. Технология бродильных производств . 2-е изд., перераб. И доп. М.: Пищевая промышленность. 1980. 596 с.

12 Ліпєц А.А. Технологія крохмалю та крохмалепродуктів: навч. посібник. К.: НУXT, 2003. 168 c. 
between the constituent parts of the grain that exhibit lubricating and propping effects, which significantly weakens the bonds between the membranes, the embryo and the endosperm. In the experiments, the grain was soaked at $40-48^{\circ} \mathrm{C}$ for $24-48$ hours to moisture of $35-45 \%$.

It is determined that during soaking, 5-7\% of soluble grain substances pass into the solution. Therefore, when processing the water/grain mixture in the RPA, used water, which had previously been soaked grain.

Limiting the temperature of soaking to $48^{\circ} \mathrm{C}$ is associated with the possible start of grain starch gelatinization.

Soaked grain with a moisture content of $35-45 \%$ was processed together with the water in the RPA to an average particle diameter of 300 $\mu \mathrm{m}$. At the same time, a study was conducted on the treatment of a water/grain mixture in RPA with not soaked grain.

The dependence of the change in the average particle diameter of the water-grain mixture on the number of treatment cycles and moisture is presented in Fig. 4.

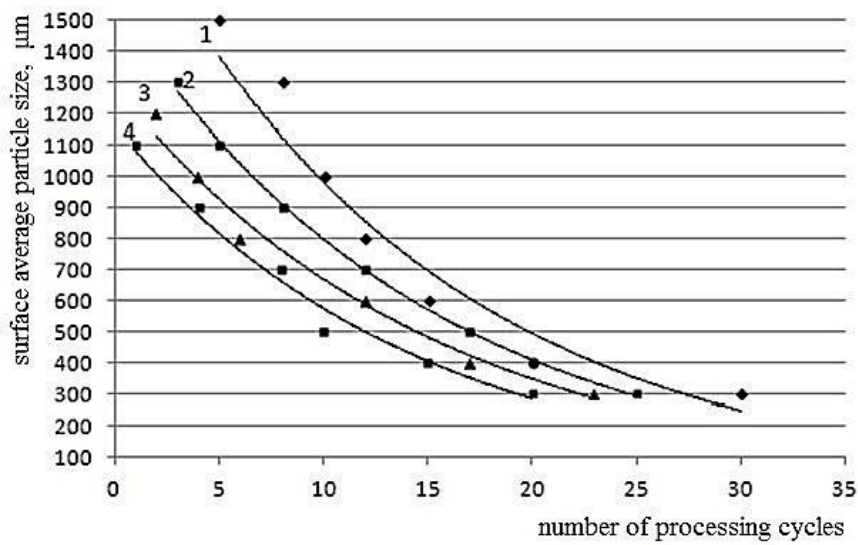

Fig. 4. Dependence of change of the surface average particle size, $\mu \mathrm{m}$ of the water/grain mixture on the number of processing cycles and grain moisture: 1 - 12\%; 2 - 35\%; 3 - 40\%; 4 - 45\%

Curve 1 in Fig. 4 corresponds to the processing of a mixture of not soaked grain with a moisture content of $12 \%$ with water. Curves $3,4,5$ correspond to the processing of grain soaked to moisture of 35,40 and 
$45 \%$ respectively. It is found that the increase in grain moisture because of soaking allows reducing the number of processing cycles from 30 to 20-23 to achieve an average particle diameter of $300 \mu \mathrm{m}$.

In subsequent studies, the influence of moisture of soaked and not soaked grain on temperature change during processing in RPA was determined (Fig. 5).

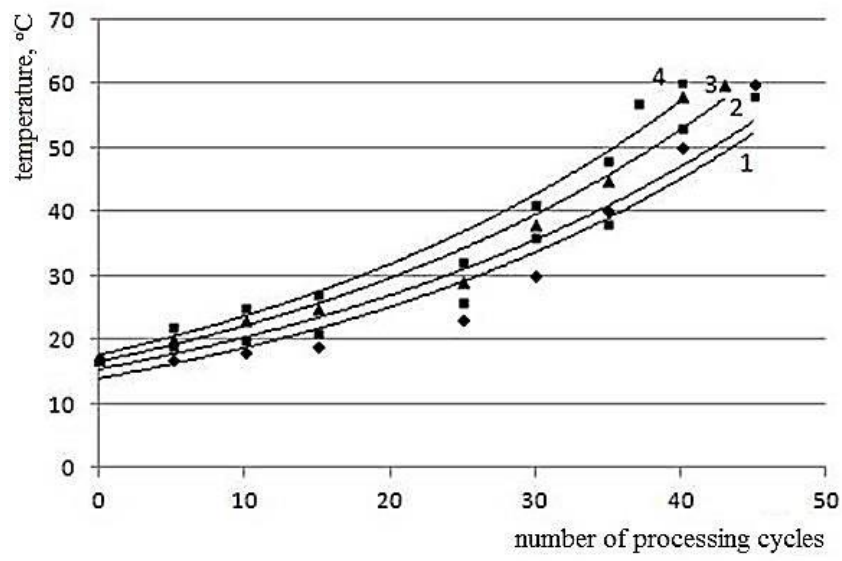

Fig. 5 The dependence of the temperature of the water/grain mixture on the number of cycles with grain moisture: $1-12 \% ; 2-35 \% ; 3-40 \% ; 4-45 \%$

This figure shows that the general tendency of all curves is to increase the temperature of the mixture with increasing number of processing cycles. From 5 to 25 cycles of treatment, the temperature of the mixture rises much less than 25 and above. This is because in the initial processing period the dispersion is not very large. With the increase in the number of processing cycles over 25 , the particle size becomes 300-500 microns.

With this particle size and temperature of $30-35^{\circ} \mathrm{C}$, the s starch gelatinization begins, which extremely increases the viscosity of the medium. With increasing viscosity, the dissipation energy increases and, as a consequence, the temperature increases. The higher the moisture content of the grain, the more swollen it becomes, the intermolecular bonds weaken and the dispersion process is faster. Consequently, the starch is faster gelatinized and the temperature rises faster. With 
increasing grain moisture from 12 to $45 \%$ at 30 treatment cycles, the temperature rises from 30 to $40^{\circ} \mathrm{C}$.

According to the results of the experiments, it can be concluded that pre-soaking the grain for 48 hours with water at a temperature of $45^{\circ} \mathrm{C}$, has a positive effect on its further processing in RPA.

The duration of dispersion is reduced by $20-25 \%$, the temperature of the mixture is increased by 1.2-1.3 times faster and the power consumption of RPA is reduced by $15-20 \%$.

Reducing the number of processing cycles leads to a reduction in the duration of the dispersion process and a reduction in energy costs ${ }^{13}$.

Research results have improved the technology of preparation of wort of alcohol production ${ }^{14}$.

Adding to the process the rotor-pulsating apparatus allowed to reduce energy consumption by $30 \%$ in the process of boiling, to reduce the duration of the process twice, to reduce the loss of fermentable substances from $8 \ldots 10 \%$ to $2 \ldots 4 \%$, to increase the yield of alcohol by a unit of raw material by $1.5 \ldots 3.0 \%$.

The dispersion of starchy raw materials and their boiling are also steps in the production of liquid feed for cattle, in particular pigs. The main part of the compound feed is cereals, because they contain in such large quantities the following vital elements: carbohydrates, minerals, vitamins. Improvement of the technology of preparation of liquid feeds by the use of RPA as a disperser-mixer of water-grain mixture has led to significant economic effect ${ }^{15,16}$.

13 Ободович А.Н., Лымарь А.Ю. Особенности переработки влажного зерна в роторно-пульсационном аппарате (РПА). Енергетика та автоматика. 1999. № 3. С. 119-123.

i4 Ободович А.Н., Грабова Т.Л., Коба А.Р., Горячев О.А. Совершенствование технологии приготовления сусла из крахмалосодержащего сырья в спиртовом производстве с применением дискретно - импульсного ввода энергии. Промышленная теплотехника. 2007. т. 29, № 4. С. 59-63.

${ }^{15}$ Ободович А.Н., Лымарь А.Ю., Сидоренко В.В., Миронец И.Н., Бачинский А.С. Совершенствование технологии приготовления комбикормов для сельскохозяйственных животных с применением метода дискретноимпульсного ввода энергии (ДИВЭ). Науковий вісник НУБІП. 2012. Вип. 174. C. $148-153$.

16 Ободович А.Н., Сидоренко В.В., Лымарь А.Ю., Миронец И.Н. Использование дискретно-импульсного метода ввода энергии (ДИВЭ) для интенсификации приготовления жидких кормов для сельскохозяйственных животных на основе барды. Вібрації в техніці та технологіях. 2013. № 2 (70). C. $190-195$. 


\section{Application of the DPIE method in biotechnology}

The high dispersion ability of the rotor-pulsating apparatus has been effectively used in the processes of absorption of poorly soluble gases, primarily due to the creation of a sufficiently high specific surface contact phase ${ }^{17}$. The main mechanism of gas phase dispersion was the crushing of gas bubbles under the action of shear stresses in the gap between the rotor and the stator ${ }^{18}$.

The dissolution of oxygen, which is also a poorly soluble gas, in the culture fluid underlies the technology of growing baker's yeast Saccharomyces cerevisiae.

The rate of dissolution of oxygen for tubular and box bubbling air distribution systems at an air flow rate of $100 \mathrm{~m}^{3}$ per $1 \mathrm{~m}^{3}$ of aerated medium per hour is about $1.4-1.6 \mathrm{~kg} / \mathrm{m}^{3} \cdot \mathrm{h}$. Given that the rate of its absorption of yeast is $1.5-2 \mathrm{~kg} / \mathrm{m}^{3} \cdot \mathrm{h}$, it can be concluded, that the process of gas distribution in the aerators is one of the inhibiting factors in the technology of cultivation of yeast, and the improvement of the air distribution system is relevant.

To study the process patterns of oxygen absorption in the culture fluid using the DPIE method in the process of deep cultivation of aerobic microorganisms a setup (fermenter) was designed shown in Fig. 6a. The RPA was the aerator-mixer, the rotor-stator assembly of which is shown in Fig. 6b. In order to ensure the conditions of the cultivation process, the system provided an air supply system to the culture fluid. The optimal temperature regime in the fermenter was ensured by the circulation of the coolant in the heat exchange jacket. The variation parameters were the speed of rotation of the rotor assembly and the thickness of the gap between rotor and stator, and the associated parameter, the shear flow rate.

The Saccharomyces cerevisiae yeast nutrient medium is typically a water/grain mixture (wort) with nitrogen and phosphorus nutrition. Molasses, a by-product of sugar production, is an alternative nutrient medium for cultivation of Saccharomyces cerevisiae. Molasses with a solids content of 3 to $10 \%$ were used in the studies.

In Fig. 7 shows the dependence of the concentration of dissolved oxygen in the wort on the number of cycles of treatment, at a speed of

${ }^{17}$ Долинский А.А., Басок Б. И., Шетанков О.К., Чайка А.И. Энергосберегающие абсорбционные технологии в производстве газированных напитков. Промыиленная теплотехника. 2001. Т. 23, № 4-5. С. 137-140.

${ }^{18}$ Корнюшенко Д.А., Блиничев В.И., Бондарева Т.И. Адсорбция диоксида углерода водой при импульсном высокоэнергетическом воздействии. Изв. ВУЗов, Химия и химическая технология. 2003. Т. 46, Вып. 5. С. 94-97. 
rotation of the rotor assembly $47.75 \mathrm{rpm}$. The volume of liquid was $60 \mathrm{l}$, the period of one cycle $-40 \mathrm{sec}$.

Analyzing the curves of Figs. 7 it can be determined that with increasing concentration of solids in the nutrient medium, the solubility of oxygen decreases. However, given that the equilibrium concentration of dissolved oxygen in molasses solutions is much lower than in water, it is sufficient to process the medium in two cycles to achieve these values.

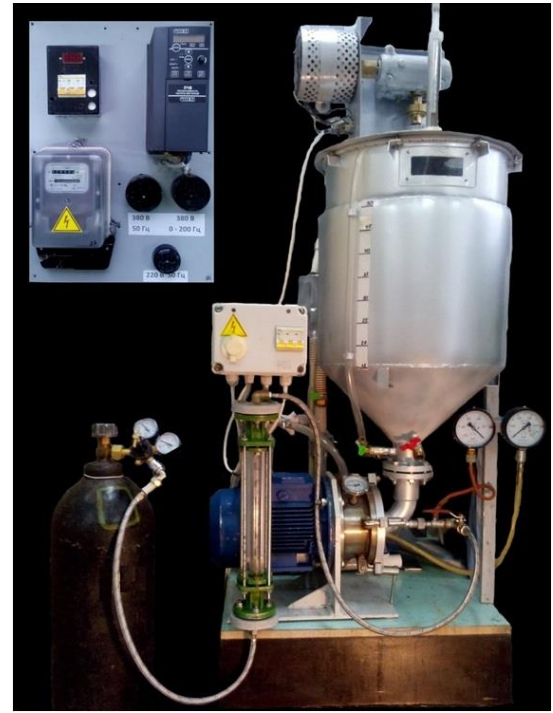

a)

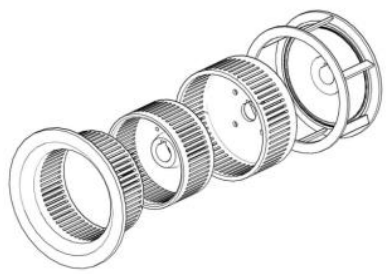

b)

Fig. 6. Experimental setup (fermenter) to study the patterns of oxygen absorption in the culture fluid using the DPIE method in the process of deep cultivation of aerobic microorganisms: a) appearance;

b) the rotor stator assembly

Studies to determine the technological parameters of cultivation were carried out with an initial concentration of yeast $20 \mathrm{~g} / \mathrm{l}$. The volume of the culture fluid was 60 liters. Yeast was cultivated for $8 \mathrm{~h}$. The variation parameter was the shear flow rate.

Figure 8 shows the dynamics of the accumulation of yeast mass during the cultivation period at a shear flow rate of $11410^{3} \mathrm{~s}^{-1}$, which was optimal in this series of studies. 


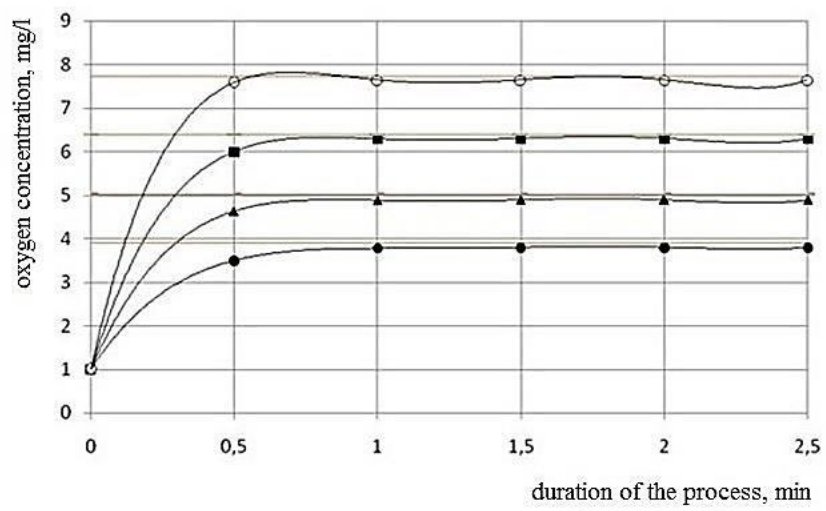

Fig. 7. Dependence of dissolved oxygen concentration on the number of processing cycles at dry matter concentration: $\bigcirc-$ water; $-3 \%$; $\Delta-5 \%$; $-10 \%$. (rotation speed of the rotary assembly $47,75 \mathrm{rpm}$, the number of holes -60 , the cylinder gap -150 microns)

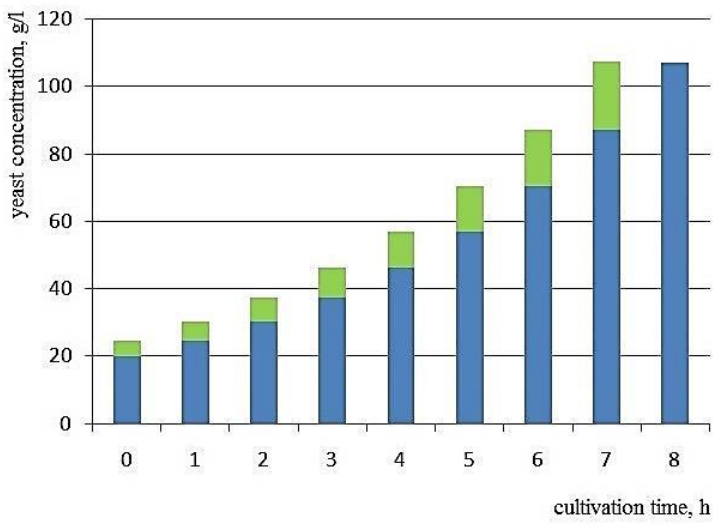

Fig. 8. Dynamics of yeast accumulation at the shear flow rate of $11410^{3} \mathrm{~s}^{-1}$

On the basis of the obtained data, the values of the specific rates of growth of the yeast with a solids content of 3 to $10 \%$ were calculated. The results of the calculations are presented in Fig. 9. It is found that with increasing flow shear rate, the specific rate of growth of yeast increases. Its maximum value is reached at a flow rate of $114 \cdot 10^{3} \mathrm{~s}^{-1}$. 
With the further increase of the shear flow rate, the specific growth rate decreases. As the solids content in the culture fluid decreases, the specific rate increases, which is explained by the higher solubility of oxygen in less concentrated media.

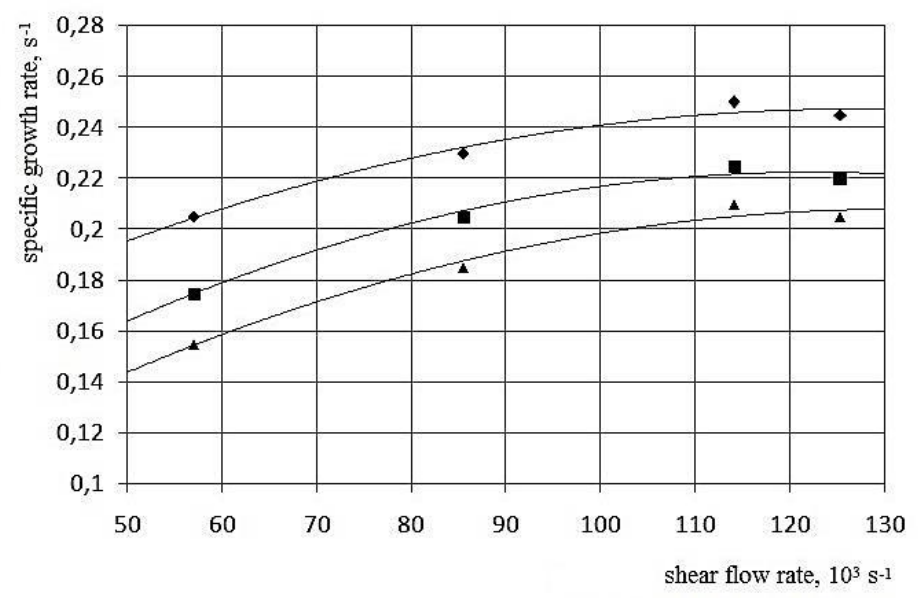

Fig. 9. Dependence of specific growth rate of yeast on the shear flow rate at the dry matter concentration in the nutrient medium:

$$
\Delta-10 \% ;-5 \% ;-3 \%
$$

On the basis of the data obtained on the accumulation of yeast biomass at the last stage of cultivation, the rate of oxygen transfer in the culture fluids was determined. In determining the effect of DIVE mechanisms on the mass transfer rate, an important factor is the gap between rotor and stator, the effect of which takes into account such an indicator as the shear flow rate, which is defined as the ratio of the velocity of the medium flow in the radial direction to the thickness of the gap between rotor and stator.

Data showing the dependence of the oxygen mass transfer rate on the shear flow rate at different solids content in the culture fluid are presented in Fig. 10. 


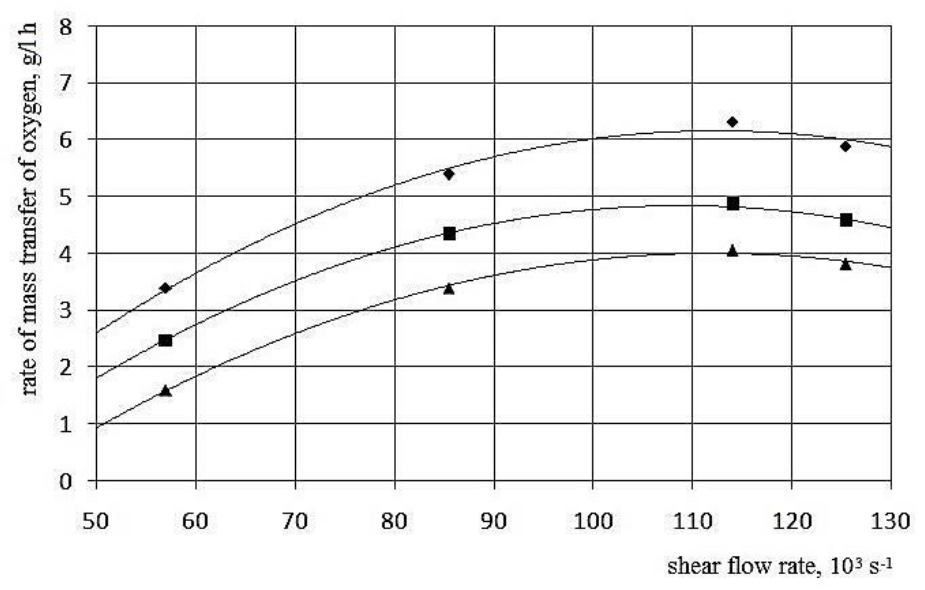

Fig. 10. Dependence of oxygen mass transfer rate on shear flow rate at dry matter concentration: $\Delta-10 \% ; \square-5 \% ;-3 \%$

It is determined that with increasing flow shear rate, the oxygen transfer rate increases. The optimal range of values of the flow shear rate is in the range $90-114 \cdot 10^{3} \mathrm{~s}^{-1}$. It has also been found that the rate of mass transfer decreases with increasing solids content in the medium.

Analysis of the results of the studies suggests that increasing the shear rate to $114 \cdot 10^{3} \mathrm{~s}^{-1}$ intensifies the value of the specific rate of growth of yeast at different concentrations of solids in the medium. With an increase in the shear flow rate of more than $114 \cdot 10^{3} \mathrm{~s}^{-1}$, the specific rate of yeast growth decreases. There may be several factors behind this.

The first is that the increase in the rate of mass transfer promotes faster and more complete entry of nutrients into the yeast cell, which may exceed the amount required for their vital activity. In this regard, cell growth is slowed or stopped altogether. Excess oxygen and nutrients in the yeast cell can lead to its death.

Another factor is that in order to achieve a high rate of dissolution of oxygen, "rigid" conditions for the processing of the medium in the RPA, i.e. high angular speeds of rotation of the rotors, pulsation frequencies, shear flow rates, are required. At the same time, high shear stresses are formed in the gap between rotor and stator, which can lead to the destruction of the cell wall. 
In order to test these assumptions, the effect of flow shear rate on the physiological state of yeast cells was studied. The results of the studies are shown in table 2.

Table 2

The dependence of the number of damaged cells (million cells) on the shear flow rate in the RPA

\begin{tabular}{|c|c|c|c|c|c|c|c|c|c|}
\hline Shear flow rate, & \multicolumn{10}{|c|}{ duration of processing, $\mathbf{~}$} \\
\cline { 2 - 11 } $\mathbf{1 0}^{\mathbf{3}} \mathbf{s}^{-\mathbf{1}}$ & $\mathbf{0}$ & $\mathbf{1}$ & $\mathbf{2}$ & $\mathbf{3}$ & $\mathbf{4}$ & $\mathbf{5}$ & $\mathbf{6}$ & $\mathbf{7}$ & $\mathbf{8}$ \\
\hline 85,46 & 2 & 2 & 2 & 2 & 3 & 3 & 4 & 4 & 4 \\
\hline 114 & 2 & 2 & 2 & 3 & 3 & 4 & 4 & 4 & 5 \\
\hline 125,4 & 2 & 3 & 3 & 5 & 5 & 6 & 6 & 9 & 10 \\
\hline bubbling & 2 & 2 & 2 & 2 & 2 & 2 & 2 & 3 & 3 \\
\hline
\end{tabular}

It is found that with increasing flow shear rate from 85.46 to 125.4 the number of dead cells increases.

\section{CONCLUSIONS}

The method of discrete-pulsed energy input, as a method that intensifies the processes of heat and mass transfer in two or multicomponent gas-liquid, liquid-solid systems, has been widely used in various industries, in particular the food industry. The application of the DPIE method allows reducing energy costs for the processes of mixing, homogenization, dispersion, emulsification, heating, the duration of these processes, and the amount of equipment.

\section{SUMMARY}

The section presents the results of applying the method of discrete pulsed energy input (DPIE) in food technology. Examples of the use of the method and rotor-pulsating apparatuses in which it is implemented in several technologies are considered. The results of the application of the DPIE method in the technologies for processing starch-containing raw materials are presented. The influence of the ratio of water to grain, the number of processing cycles, the angular speed of the rotor, the thickness of the gap between the rotor and the stator on the degree of dispersion of the grain is considered. The effect of preliminary soaking of grain on the efficiency of its processing in a rotor-pulsating apparatus is considered. It has been determined that the optimal processing regime is the following: the ratio of grain to water is 1: 2 , the rotor angular speed is 300 , the 
thickness of the gap is $500 \mu \mathrm{m}$, the number of processing cycles is 20 . The research data on the cultivation of Saccharomyces cerevisiae yeast using rotor- pulsating apparatus as an aerator-mixer are presented. It was found that the maximum specific growth rate of yeast, equal to $0.25 \mathrm{~s}^{-1}$ during cultivation for 8 hours, is achieved at a shear flow rate of $114 \cdot 10^{3} \mathrm{~s}^{-1}$.

\section{REFERENCES}

1. Иванец В.Н., Бакин И.А., Ратников С.А. Процессы и аппараты пищевых производств: Учебное пособие. Кемерово: Кемеровский технологический институт пищевой промышленности, 2004. 180 с.

2. Микро- и наноуровневые процессы в технологиях ДИВЭ: Тематический сборник статей /под общей ред. А.А. Долинского; Институт технической теплофизики НАН Украины. К.: Академпериодика, 2015. 464 с.

3. Накорчевский А.И., Басок Б.И., Рыжкова Т.С. Гидродинамика роторно-пульсационных аппаратов. Инженерно-физический журнал. 2002. Т.75, № 2. С. 58-68.

4. Rodgers T. High-Shear Mixing: Applications in the Food Industry [Електронний ресурс] / T. Rodgers, L. Trinh // Elsevier BV. - 2016. Режим доступу до ресурсу: https://doi.org/10.1016/B978-0-08-100596$5.03095-\mathrm{X}$

5. Басок Б.И., Ободович А.Н., Мартыненко М.П., Коба А.Р., Горячев О.А. Интенсификация технологии производства сгущенного молока с сахаром посредством роторно-пульсационных аппаратов. Промышленная теплотехника. 2005. Т. 27, № 1. С. 38-41

6. Ободович А.Н. Хибина М.А., Боряк Л.А., Ободович А.А., Тесля А.И. Интенсификация производства глюкозо-фруктозных сиропов за счет механохимической деструкции. Промышленная теплотехника. 2006. Т. 28, № 3. С. 44-49.

7. Басок Б.И. Пироженко И.А., Булавка Д.В. Дисперсный анализ соевой пасты, полученной при роторно-пульсационной гомогенизации. Промышленная теплотехника. 2003. Т. 25, № 4. C. 88-92.

8. Грищенко А.В., Терлецкая Я.Т., Шаркова Н.А., Жукотский Э.К. Разработка высокобелковых композиций на соевой основе для лечебно-профилактического питания. Промышленная теплотехника. 2003. Т. 25, № 4. С. 115-116. 
9. Шаркова Н.О., Жукотський Е.К., Грищенко Г. В. Особливості технології виробництва соєвих продуктів. Промышленная теплотехника. 2004. Т. 26, № 6. С. 93-96.

10. Долинский А.А., Басок Б.И. Роторно-импульсный аппарат. 2. Локальный импульсный нагрев жидкости. Промышленная теплотехника. 1999. Т. 21, № 1. С. 3-5.

11. Мальцев П.М. Технология бродильных производств. 2-е изд., перераб. и доп. М.: Пищевая промышленность. 1980. 596 с.

12. Ліпєц А.А. Технологія крохмалю та крохмалепродуктів: навч. посібник. К.: НУХТ, 2003. 168 с.

13. Ободович А.Н., Лымарь А.Ю. Особенности переработки влажного зерна в роторно-пульсационном аппарате (РПА). Енергетика та автоматика. 1999. № 3. С. 119-123.

14. Ободович А.Н., Грабова Т.Л., Коба А.Р., Горячев О.А. Совершенствование технологии приготовления сусла из крахмалосодержащего сырья в спиртовом производстве с применением дискретно - импульсного ввода энергии. Промыиленная теплотехника. 2007. т. 29, № 4. С. 59-63.

15. Ободович А.Н., Лымарь А.Ю., Сидоренко В.В., Миронец И.Н., Бачинский А.С. Совершенствование технологии приготовления комбикормов для сельскохозяйственных животных с применением метода дискретно-импульсного ввода энергии (ДИВЭ). Науковий вісник НУБІП. 2012. Вип. 174. С. 148-153.

16. Ободович А.Н., Сидоренко В.В., Лымарь А.Ю., Миронец И.Н. Использование дискретно-импульсного метода ввода энергии (ДИВЭ) для интенсификации приготовления жидких кормов для сельскохозяйственных животных на основе барды. Вібрації в техніияі та технологіях. 2013. № 2 (70). С.190-195.

17. Долинский А.А., Басок Б. И., Шетанков О.К., Чайка А.И. Энергосберегающие абсорбционные технологии в производстве газированных напитков. Промышленная теплотехника. 2001. Т. 23, № 4-5. C. 137-140.

18. Корнюшенко Д.А., Блиничев В.И., Бондарева Т.И. Адсорбция диоксида углерода водой при импульсном высокоэнергетическом воздействии. Изв. ВУЗов, Химия и химическая технология. 2003. Т.46, Вып. 5. С. 94-97.

Information about the authors: 
Obodovych O. M.,

Doctor of Engineering Science, Senior Researcher,

Chief Researcher of Department Thermophysics of Pulsed Processes in Disperse Systems Institute of Engineering Thermophysics of National Academy of Sciences of Ukraine 2a, Marii Kapnist (Zhelyabova) str., Kyiv, 03057, Ukraine

Sydorenko V. V.,

Candidate of Engineering Science, Senior Researcher of Department Thermophysics of pulsed Processes in Disperse Systems Institute of Engineering Thermophysics of National Academy of Sciences of Ukraine 2a, Marii Kapnist (Zhelyabova) Str., Kyiv, 03057, Ukraine 